\title{
FEASIBILITY OF USING CHLORAL HYDRATE TO INCREASE THE TOXICITY OF PARAPHENYLENEDIAMINE (PPD) AGAINST THREE RODENT SPECIES UNDER LABORATORY CONDITIONS \\ Baghdadi, S. A. S. ; A. S. S. Desoky ${ }^{* *}$ H. S.K. Ahmed and M. A. A. Aboshosha* \\ * Agric. Zoology and Nematology Dept., Faculty of Agric., Al-Azhar University.Saudi_Elkayal@yahoo.com

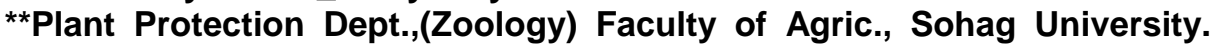 abdelalem2011@yahoo.com
}

\begin{abstract}
The present work aims to use three concentrations (1,2 and 3\%) of Chloral hydrate adding to $4 \%$ Paraphenylenediamine (PPD) (Saudi, 2012) in order to improve of PPD against three rodent species: Norway rat, Rattus norvegicus, Nile grass rat, Arvicanthis niloticus and house mice, Mus musculus under laboratory conditions. The results showed a high rate of consumption of the bait when using with the low concentrations of Chloral hydrate. While the 4\% PPD without additions were the first in bait consumption. Rodent females consumed high rate of baits as compared with males. The consumption were (45.60 and 63.60), (56.80 and 83.80), (21.20 and 32.20 g/animal) for males and females of Norway rat, $R$. norvegicus, Nile grass rat, $A$ niloticus and house mice, $M$. musculus respectively. Mean of consumed baits were: 48.43, 76.38 and $27.13 \mathrm{~g}$ /animal Norway rat, $R$. norvegicus, Nile grass rat, $A$. niloticus, and house mice, $M$. musculus respectively. The results also indicated that the period of stay alive of tasted animals increases gradually with an increasing of Chloral hydrate (carried on crushed maize) compared to using also control bait. Females were most durable and lasted the longest life comparative with males for all rodent species tested. These periods were (9.10 and 12.90), (8.00 and 11.85), (7.75 and 13.05 day) for Norway rat, $R$. norvegicus, Nile grass rat, $A$. niloticus and house mice, M. musculus, respectively. Also Norway rat, $R$. norvegicus showed a longer period of survival than the other two species. On the other hand, the reduction in weight of the males of the three tasted rodent species was less than the reduction in weight of females when using Chloral hydrate concentrations carried on crushed maize.

Keywords:Chloral hydrate, House mice, Nile grass rat, Norway rat, Paraphenylenediamine
\end{abstract}

\section{INTRODUCTION}

The acute toxicity of chloral hydrate studied in CD-1 mice. Groups of 8 male and 8 female mice were given chloral hydrate by gavage in distilled water at $300,600,900,1,200,1,500$, and $1,800 \mathrm{mg} / \mathrm{kg}$. No deaths occurred at $900 \mathrm{mg} / \mathrm{kg}$ or below in either sex. The calculated $\mathrm{LD}_{50}$ for females was $1,265 \mathrm{mg} / \mathrm{kg}$ and for males was $1,442 \mathrm{mg} / \mathrm{kg}$. Effects were seen within 10 minutes from dosing. The mice became sedated at $300 \mathrm{mg} / \mathrm{kg}$. At 600 and $900 \mathrm{mg} / \mathrm{kg}$, the animals became lethargic and exhibited loss of righting reflex. Respiration was markedly inhibited at $1,200,1,500$, and $1,800 \mathrm{mg} / \mathrm{kg}$. Inhibition of respiration appeared to be the immediate cause of death. Most 
deaths occurred within 4 hours at $1,800 \mathrm{mg} / \mathrm{kg}$. But at 1,200 and 1,500 $\mathrm{mg} / \mathrm{kg}$, some deaths occurred after 4 hours, with all deaths occurring within 24 hours.

The sub chronic toxicity of chloral hydrate has been studied in CD1 mice and Sprague-Dawley rats. Administration of chloral hydrate to mice by gavage at daily doses of 14.4 and $144 \mathrm{mg} / \mathrm{kg}$ body weight for 14 consecutive days resulted in an increase in relative liver weight and decrease in spleen size. No other changes were seen. Administration of chloral hydrate to mice in drinking-water for 90 days at concentrations of 0.07 and $0.7 \mathrm{mg} / \mathrm{ml}$ resulted in dose-related hepatomegaly in males only and significant changes in hepatic microsomal enzymes in both males and females, indicative of hepatic toxicity (Sanders et al., 1982). The metabolism of chloral hydrate $(\mathrm{CH})$ was investigated in the isolated perfused rat liver system. The experiments were performed on rats that were administered carbon tetrachloride $\left(\mathrm{CCl}_{4}\right)$ subcutaneously for 15 weeks to induce chronic liver damage and on untreated rats. Clearance of $\mathrm{CH}$ from the perfusion system was lower in damaged liver than in control liver. In both groups, $50-70 \%$ of the added $\mathrm{CH}$ was excreted into perfusate as trichloroethanol (TCE) and trichloroacetic acid (TCA) within $120 \mathrm{~min}$. The TCE/TCA ratio was 1:1.3 in the control group compared to 2:1 in the damaged liver group. The findings suggest that $\mathrm{CH}$ metabolism in the liver is affected by chronic damage (Toshihiro et al., 1987).

\section{MATERIALS AND METHODS}

Rodents were trapped from Al-Azhar University Experimental Farm in Assiut, and then transferred into the laboratory. The captured rodents were classified into species and sexed mature males and females. The healthy animals from Rattus norvegicus and A. niloticus (100-160g in weight) and the M. musculus $(25-30 \mathrm{~g})$ were chosen. All rodent species were divided into groups each group contained 10 mature animals (5 males and 5 females). The animals were singly caged and suitably accommodation in the laboratory for ten days, provided with enough crushed maize bait and water. The tests of the material concentrations were $1 \%$ to $3 \%$ of Chloral hydrate mixed with 4\% PPD carried on crushed maize as bait compared with 4\% PPD only as control bait. The animals were left until death or 21 days. The time of mortality, bait consumption, susceptibility for males and females and weight fluctuations were determined. The obtained data were statistically analyzed using $\mathrm{F}$ test for recognizing the significant among the tested treatments.

\section{RESULTS AND DISCUSSION}

\section{1- Consumed bait of Chloral hydrate between three rodent species:}

Data in Table (1) and Figure (1) revealed the consumption of baits by three rodent species (Norway rat, $R$. norvegicus, Nile grass rat, $A$. niloticus and house mice, M. musculus). Animals were fed on various concentrations of Chloral hydrate carried on crushed maize. Mean of consumed baits were: $48.43,76.38$ and $27.13 \mathrm{~g} / \mathrm{animal}$ for three rodent species, respectively. 
Records of each concentration against three rodent species were: 50.53 , 41.40 and $38.20 \mathrm{~g} /$ animal for $1 \%, 2 \%$ and $3 \%$ Chloral hydrate respectively. While, the control treatment was $72.43 \mathrm{~g} /$ animal. In case of $R$. norvegicus, the consumed baits were: $45.60,34.10$ and $29.60 \mathrm{~g} /$ animal, were: $70.30,62.90$ and $59.20 \mathrm{~g}$ /animal for A. niloticus. And $26.70,27.20$ and $25.80 \mathrm{~g} /$ animal for M. musculus when used the concentrations of $1 \%, 2 \%$ and $3 \%$ chloral hydrate carried on crushed maize, respectively. Highly significant differences were counted between mean consumed bait by $R$. norvegicus, $A$. niloticus and $M$. musculus. There were significant differences between mean consumption of $1 \%$ and $2 \%$ and between $1 \%$ and $3 \%$ and in-significant difference were records when used $2 \%$ and $3 \%$ chloral hydrate carried on crushed maize for the three rodent species.

The obtained data revealed that the $A$. niloticus, is able to consume high baits as compared with the other two species $R$. norvegicus, and $M$. musculus, this may be due mainly to the long period of time that $A$. niloticus, can stay a life as compared with the other two species.

The same Table showed also the effect of chloral hydrate on males and females of the three rodent species. Males consumed 40.65, 61.35 and $21.55 \mathrm{~g} /$ animal. While females consumed $56.20,91.40$ and $32.70 \mathrm{~g} /$ animal. As recorded for $R$. norvegicus, $A$. niloticus, and M. musculus, respectively. Significant differences were noticed between mean consumption of males and females for the three rodent species. Highly significant differences also were counted between mean consumption of bait for males and females of $R$. norvegicus, A. niloticus, and $M$. musculus $(41.18$ and $60.10 \mathrm{~g} /$ animal respectively, Agreement with (Frederick, 1993 and Sanders et al., 1982).

Table (1): Effect of various concentrations of Chloral hydrate carried on crushed maize on bait consumption of three rodent species under laboratory conditions.

\begin{tabular}{|c|c|c|c|c|c|}
\hline \multicolumn{2}{|c|}{$\begin{array}{ll} & \text { Species } \\
\text { Treatments. } & \end{array}$} & R. norvegicus & A. niloticus & M. musculus & Mean \\
\hline \multirow{4}{*}{ Male } & $1 \% \mathrm{C.H}$ & $45.60 \mathrm{i}$ & $56.80 \mathrm{~g}$ & 21.200 & $41.20 \mathrm{c}$ \\
\hline & $2 \%$ C.H & $30.00 i$ & $51.60 \mathrm{~h}$ & $22.60 \mathrm{no}$ & $34.73 \mathrm{~g}$ \\
\hline & $3 \%$ C.H & $25.20 n$ & $51.20 \mathrm{~h}$ & $22.40 \mathrm{no}$ & $32.93 \mathrm{~g}$ \\
\hline & control & $61.80 \mathrm{f}$ & $85.80 \mathrm{bc}$ & 20.000 & $55.87 \mathrm{c}$ \\
\hline \multicolumn{2}{|l|}{ Mean } & $40.65 \mathrm{~d}$ & $61.35 \mathrm{~b}$ & $21.55 \mathrm{f}$ & $41.18 \mathrm{~B}$ \\
\hline \multirow{4}{*}{ Female } & $1 \%$ C.H & $63.60 \mathrm{~b}$ & $83.80 \mathrm{c}$ & $32.20 \mathrm{Im}$ & $59.87 \mathrm{~b}$ \\
\hline & $2 \%$ C.H & 38.20 & $74.20 \mathrm{~d}$ & $31.80 \mathrm{Im}$ & $48.07 \mathrm{~d}$ \\
\hline & $3 \%$ C.H & $34.00 \mathrm{kl}$ & $67.20 \mathrm{e}$ & $29.20 \mathrm{~m}$ & $43.47 \mathrm{e}$ \\
\hline & control & $89.00 \mathrm{~b}$ & $140.40 \mathrm{a}$ & $37.60 \mathrm{jk}$ & $89.00 \mathrm{a}$ \\
\hline \multicolumn{2}{|l|}{ Mean } & $56.20 \mathrm{c}$ & $91.40 \mathrm{a}$ & $32.70 \mathrm{e}$ & $60.10 \mathrm{~A}$ \\
\hline \multirow{4}{*}{$\begin{array}{l}\text { Mean of } \\
\text { male and } \\
\text { female }\end{array}$} & $1 \%$ C.H & $45.60 \mathrm{~b}$ & $70.30 \mathrm{c}$ & $26.70 \mathrm{ij}$ & $50.53 \mathrm{~A}$ \\
\hline & $2 \%$ C.H & $34.10 \mathrm{~g}$ & $62.90 \mathrm{~d}$ & $27.20 \mathrm{hij}$ & $41.40 \mathrm{C}$ \\
\hline & $3 \%$ C.H & $29.60 \mathrm{~h}$ & $59.20 \mathrm{e}$ & $25.80 \mathrm{j}$ & $38.20 \mathrm{D}$ \\
\hline & control & $75.40 \mathrm{~b}$ & $113.10 \mathrm{a}$ & $28.80 \mathrm{hi}$ & $72.43 \mathrm{~A}$ \\
\hline \multicolumn{2}{|l|}{ Mean } & $48.43 \mathrm{~B}$ & $76.38 \mathrm{~A}$ & $27.13 \mathrm{C}$ & 50.64 \\
\hline
\end{tabular}




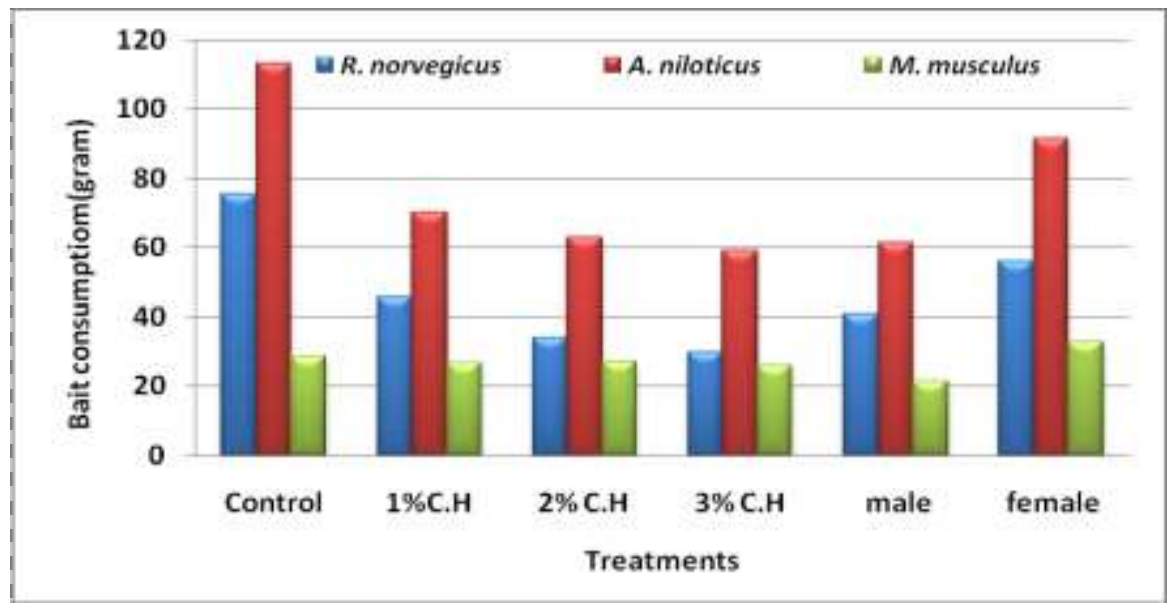

Figure (1): Effect of various concentrations of Chloral hydrate carried on crushed maize on bait consumption of three rodent species under laboratory conditions.

\section{2- Time of death (day):}

Data in Table (2) and Figure (2) show the life period counted from treatment with poison baits until death for three rodent species $(R$. norvegicus, A. niloticus, and $M$. musculus). The mean time periods were: $11.00,9.93$ and 10.40 day/ animal for the above mentioned there species, respectively. The maximum time was 11.00 day/ animal followed by 10.40 day/ animal and the lowest one was 9.93 day/ animal for R. norvegicus, $M$. musculus and $A$. niloticus respectively. Males of the three species remained by period of time as compared with females, the periods were 9.10, 8.00 and 7.75 day/ animal for males and 12.90, 11.85 and 13.05 day/ animal for females of R. norvegicus, A. niloticus and $M$. musculus . Rodents treated with $1 \%$ Chloral hydrate still alife for $9.70,8.00$ and 9.20 day/ animal, while in $2 \%$ concentration resulted in $11.80,9.30$ and 10.70 day/ animal. While, $3 \%$ showed $14.10,10.90$ and 12.80 day/ animal as compared with 8.40, 11.50 and 8.90 day/ animal for control bait for R. norvegicus, A. niloticus and M. musculus, respectively. Significant differences were recorded between mean time of males and females and between the three rodent species.

Generally females are more tolerated for all concentrations of Chloral hydrate as compared with males. This may be due mainly to the fat concentrations in females body as compared with males. Agreement with The findings suggests that $\mathrm{CH}$ metabolism in the liver is affected by chronic damage (Toshihiro et al., 1987). 
Table (2): Effect of various concentrations of Chloral hydrate carried on crushed maize on survival period of three rodent species under laboratory conditions.

\begin{tabular}{|c|c|c|c|c|c|}
\hline Treatment & Species & R. norvegicus & A. niloticus & M. musculus & Mean \\
\hline \multirow{4}{*}{ Male } & $1 \% \mathrm{C} . \mathrm{H}$ & $8.00 \mathrm{kl}$ & $6.40 \mathrm{n}$ & $7.20 \mathrm{~m}$ & $7.20 \mathrm{f}$ \\
\hline & $2 \%$ C.H & $10.40 \mathrm{~g}$ & $7.60 \mathrm{Im}$ & $8.40 \mathrm{jk}$ & $8.80 \mathrm{e}$ \\
\hline & $3 \%$ C.H & 11.60 ef & $9.20 \mathrm{hi}$ & $9.60 \mathrm{~h}$ & $10.13 \mathrm{~d}$ \\
\hline & control & $6.40 \mathrm{n}$ & $8.80 \mathrm{ij}$ & $5.80 n$ & $7.00 \mathrm{f}$ \\
\hline Mean & & $9.10 \mathrm{c}$ & $8.00 \mathrm{~d}$ & $7.75 \mathrm{~d}$ & $8.28 \mathrm{~B}$ \\
\hline \multirow{4}{*}{ Female } & $1 \%$ C.H & 11.40 ef & $9.60 \mathrm{~h}$ & $11.20 \mathrm{f}$ & $10.73 \mathrm{c}$ \\
\hline & $2 \%$ C.H & $13.20 \mathrm{c}$ & $11.00 \mathrm{fg}$ & $13.00 \mathrm{c}$ & $12.40 \mathrm{~b}$ \\
\hline & $3 \%$ C.H & $16.60 \mathrm{a}$ & $12.60 \mathrm{~cd}$ & $16.00 \mathrm{a}$ & $15.07 \mathrm{a}$ \\
\hline & control & $10.40 \mathrm{~g}$ & $14.20 \mathrm{~b}$ & $12.00 \mathrm{de}$ & $12.20 \mathrm{~b}$ \\
\hline Mean & & $12.90 \mathrm{a}$ & $11.85 \mathrm{~b}$ & $13.05 \mathrm{a}$ & $12.60 \mathrm{~A}$ \\
\hline \multirow{4}{*}{$\begin{array}{l}\text { Mean of } \\
\text { male } \\
\text { and } \\
\text { female }\end{array}$} & $1 \%$ C.H & $9.70 \mathrm{e}$ & $8.00 \mathrm{~h}$ & 9.20 ef & $8.97 \mathrm{D}$ \\
\hline & $2 \%$ C.H & $11.80 \mathrm{c}$ & 9.30 ef & $10.70 \mathrm{~d}$ & $10.60 \mathrm{~B}$ \\
\hline & $3 \%$ C.H & $14.10 \mathrm{a}$ & $10.90 \mathrm{~d}$ & $12.80 \mathrm{~b}$ & $12.60 \mathrm{~A}$ \\
\hline & control & $8.40 \mathrm{gh}$ & $11.50 \mathrm{c}$ & $8.90 \mathrm{fg}$ & $9.60 \mathrm{C}$ \\
\hline \multicolumn{2}{|l|}{ Mean } & $11.00 \mathrm{~A}$ & $9.93 \mathrm{C}$ & $10.40 \mathrm{~B}$ & 10.44 \\
\hline
\end{tabular}
chloral hydrate , $\quad 3 \%$ C.H= PPD $4 \%+3 \%$ chloral hydrate.

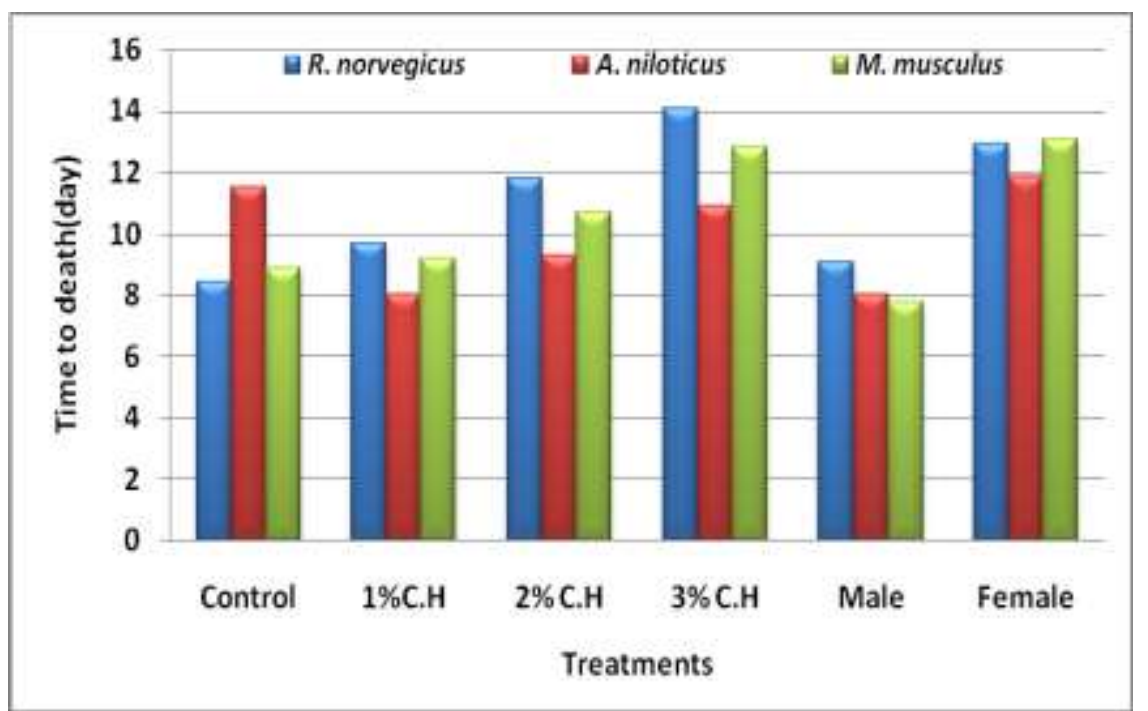

Figure (2): Effect of various concentrations of Chloral hydrate carried on crushed maize on survival period of three rodent species under laboratory conditions.

3- Effect of various concentrations of Chloral hydrate on Body weight of three rodent species:

Data in Table (3) and Figure (3) show the fluctuation of body weights of rodents after treatment with various concentrations of Chloral hydrate. High decrease in body weight was recorded for $A$. niloticus followed by $R$. norvegicus, and finally $M$. musculus with $5.28,5.20$ and $2.28 \mathrm{~g} /$ animal, 
respectively. The same trend was observed in males as compared with females $(4.15,4.00$ and 2.10 for males and $6.25,6.55$ and $2.45 \mathrm{~g} /$ animals for males of $R$. norvegicus, $A$. niloticus and $M$. musculus, respectively. In case of $R$. norvegicus high decrease was recorded when used in $2 \%, 3 \%$ and control treatment as compared with $1 \%$ Chloral hydrate, $4.60,6.80,5.70$ and $3.70 \mathrm{~g} /$ animal, respectively. The $A$. niloticus high fluctuation in control treatment $10.20 \mathrm{~g} /$ animal followed by $3.80,3.80$ and $3.30 \mathrm{~g} /$ animal for $2 \%, 3 \%$ and $1 \%$ Chloral hydrate respectively. In case of $M$. musculus was $(3.00 \mathrm{~g} / \mathrm{animal}$ in control bait) followed by $2.40,1.90$ and $1.80 \mathrm{~g} /$ animal when used $3,2,1 \%$ Chloral hydrate respectively. This may be due to the repellant taste for the highest concentrations as compared with lowest one. Highly significant difference was recorded between mean fluctuation of rodent species and significant difference was found between mean fluctuations of males as compared with females in all rodents tasted. Similar with, Frederick (1993) one male receiving $800 \mathrm{mg} / \mathrm{kg}$ died after receiving five doses. All other animals survived to receive 12 doses, though two $800 \mathrm{mg} / \mathrm{kg}$ females died before the end of the study. The final mean body weight of treatment 800 $\mathrm{mg} / \mathrm{kg}$ males was significantly less than that of the vehicle control group. In addition, the mean body weight gains of 400 and $800 \mathrm{mg} / \mathrm{kg}$ males were significantly less than that of the vehicle controls. Final mean body weights and body weight gains of all female dosed groups were similar to those of the vehicle control group. The only clinical finding attributed to chloral hydrate treatment was light sedation in the $400 \mathrm{mg} / \mathrm{kg}$ groups and heavy sedation in the $800 \mathrm{mg} / \mathrm{kg}$ dose groups; sedation subsided within 30 minutes or 3 hours, respectively. Differences in organ weights generally reflected reduced mean body weights. Mild to moderate kidney mineralization occurred in all dosed and control females; the severity of this lesion was not dose related. No treatment-related gross or microscopic lesions were observed in males or females. (Saudi and Desoky, 2013) used three concentrations (1,2 and 3\%) of neem seed extracts adding to $4 \%$ Paraphenylenediamine (PPD), the previously recommended dose in order to improve of PPD against three rodent species: white billed rat, Rattus rattus frugivorus, nile grass rat, Arvicanthis niloticus and house mice, Mus musculus under laboratory conditions.Found that Highly significant differences were counted between mean consumption of bait, time death and body weight for males and females of R. r. frugivorus, A. niloticus, and M. musculus. 
Table (3): Effect of various concentrations of Chloral hydrate carried with crushed maize on body weight of three rodent species under laboratory conditions.

\begin{tabular}{|c|c|c|c|c|c|}
\hline \multicolumn{2}{|c|}{$\begin{array}{l}\text { Species } \\
\text { Treatments. }\end{array}$} & R. norvegicus & A. niloticus & M. musculus & Mean \\
\hline \multirow{4}{*}{ Male } & $1 \%$ C.H & $2.20 \mathrm{ijkl}$ & $2.20 \mathrm{ijkl}$ & $1.40 \mathrm{I}$ & $1.93 \mathrm{f}$ \\
\hline & $2 \%$ C.H & $3.80 \mathrm{gh}$ & $2.40 \mathrm{ijk}$ & $1.80 \mathrm{kl}$ & $2.67 \mathrm{e}$ \\
\hline & $3 \%$ C.H & $5.80 \mathrm{~cd}$ & $2.80 \mathrm{ij}$ & $2.20 \mathrm{ijkl}$ & $3.60 \mathrm{~d}$ \\
\hline & control & 4.80 ef & $8.60 \mathrm{~b}$ & $3.00 \mathrm{hi}$ & $5.47 \mathrm{~b}$ \\
\hline \multicolumn{2}{|l|}{ Mean } & $4.15 b$ & $4.00 \mathrm{~b}$ & $2.10 \mathrm{c}$ & $3.42 \mathrm{~B}$ \\
\hline \multirow{4}{*}{ Female } & $1 \%$ C.H & 5.20 def & $4.40 \mathrm{fg}$ & $2.20 \mathrm{ijkl}$ & $3.93 \mathrm{~cd}$ \\
\hline & $2 \%$ C.H & $5.40 \mathrm{de}$ & 5.20 def & $2.00 \mathrm{jkl}$ & $4.20 \mathrm{c}$ \\
\hline & $3 \%$ C.H & $7.80 \mathrm{~b}$ & 4.80 ef & $2.60 \mathrm{ijk}$ & $5.07 \mathrm{~b}$ \\
\hline & control & $6.60 \mathrm{c}$ & $11.80 \mathrm{a}$ & $3.00 \mathrm{hi}$ & $7.13 \mathrm{a}$ \\
\hline \multicolumn{2}{|l|}{ Mean } & $6.25 \mathrm{a}$ & $6.55 \mathrm{a}$ & $2.45 \mathrm{c}$ & $5.08 \mathrm{~A}$ \\
\hline \multirow{4}{*}{$\begin{array}{l}\text { Mean } \\
\text { of male } \\
\text { and } \\
\text { female }\end{array}$} & $1 \%$ C.H & $3.70 \mathrm{e}$ & 3.30 ef & $1.800 \mathrm{~h}$ & $2.93 \mathrm{D}$ \\
\hline & $2 \%$ C.H & $4.60 \mathrm{~d}$ & $3.80 \mathrm{e}$ & $1.90 \mathrm{~h}$ & $3.43 \mathrm{C}$ \\
\hline & $3 \%$ C.H & $6.80 \mathrm{~b}$ & $3.80 \mathrm{e}$ & $2.40 \mathrm{gh}$ & $4.33 \mathrm{~B}$ \\
\hline & control & $5.70 \mathrm{c}$ & $10.20 \mathrm{a}$ & $3.00 \mathrm{fg}$ & $6.30 \mathrm{~A}$ \\
\hline \multicolumn{2}{|l|}{ Mean } & $5.20 \mathrm{~A}$ & $5.28 \mathrm{~A}$ & $2.28 \mathrm{~B}$ & 4.25 \\
\hline
\end{tabular}

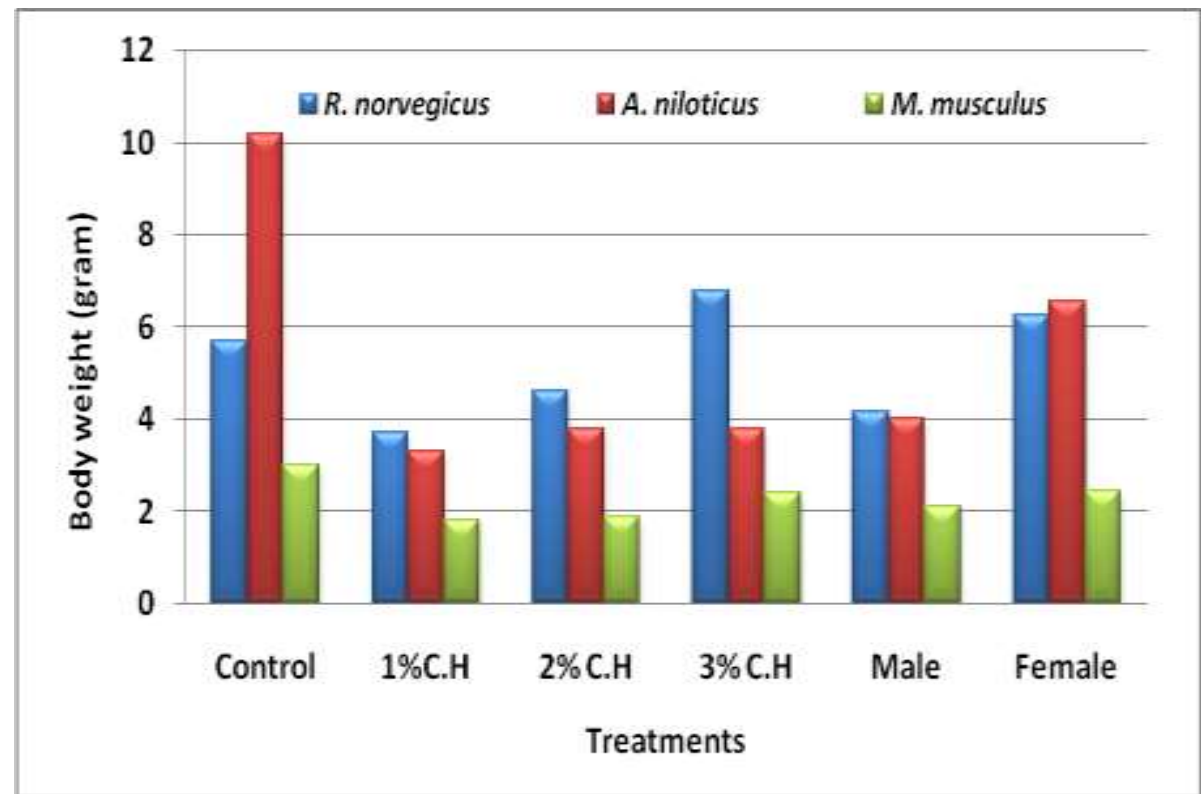

Figure (3): Effect of various concentrations of Chloral hydrate carried with crushed maize on body weight of three rodent species under laboratory conditions. 


\section{CONCLUSION}

In this work three concentrations (1,2 and $3 \%)$ of Chloral hydrate were used adding to $4 \%$ Paraphenylenediamine (PPD), the previously recommended dose in order to improve of PPD against three rodent species: Norway rat, $R$. norvegicus, Nile grass rat, $A$. niloticus and house mice, $M$. musculus under laboratory conditions. Results indicated that highly significant differences were counted between mean consumption of bait, time death and body weight for males and females of the three rodent species. These results may be useful in preparation of rodenticides baits used in rodent control programme. When use PPD in rodent control use it could be used without any additions.

\section{REFERENCES}

Frederick, A. B.;(1993): NTP Technical Report on the Toxicity and Metabolism Studies of Chloral Hydrate. Ph.D. Thesis National Center for Toxicological Research Jefferson, National Institutes of Health.

Sanders, V. M; B. M Kauffman, K .L White. (1982):Toxicology of chloral hydrate in the mouse. Environ Health Perspect 44:137-146.

Saudi, A. S. (2012): Using of some environmentaly available alternatives as rodenticides in Assiut area. Ph.D. Thesis, Fac. Agric., Al-Azhar University. pp.149.

Saudi A. S. and Desoky, A.S.S. (2013): Additions used to increase the toxicity of Paraphenylenediamine (PPD) against three rodent species under laboratory conditions, Egypt, American Journal of Oil and Chemical Technologies; ISSN (online): 2326-6589; ISSN (print): 23266570 , Volume 1, Issue 5

Toshihiro, K; H. Tatsuya; K. Haruo ; I. Susumu ; S. Tsunemi ; O. Keiki (1987): Alteration of chloral hydrate metabolism in rats with carbon tetrachloride-induced liver damage, Toxicology Letters, Volume 37, Issue 3, P: 263-268. 


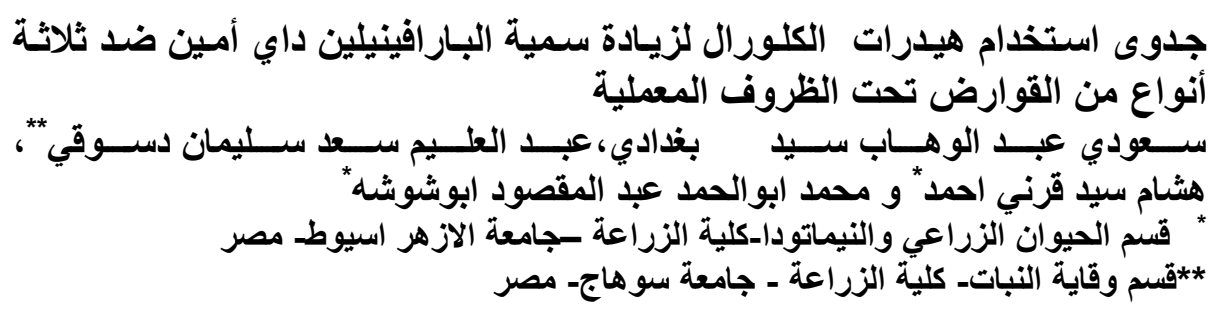

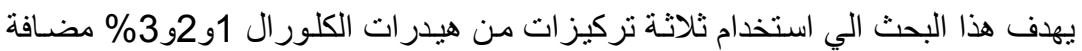

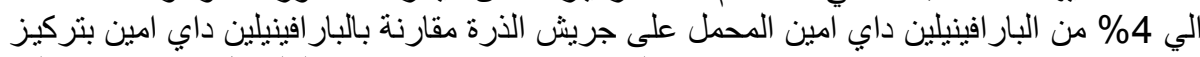



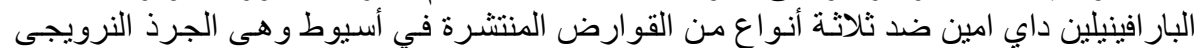

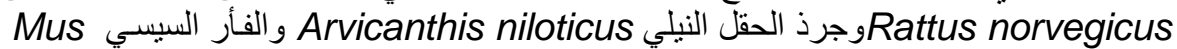
musculus

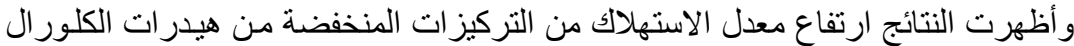

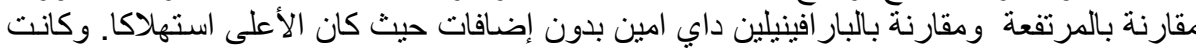

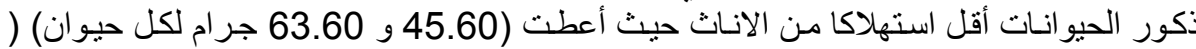

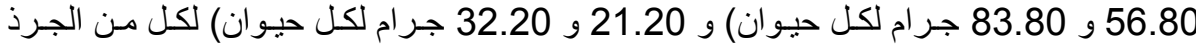

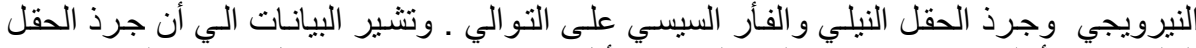



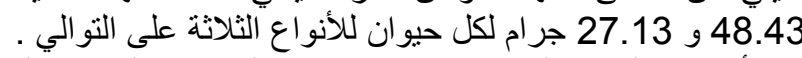

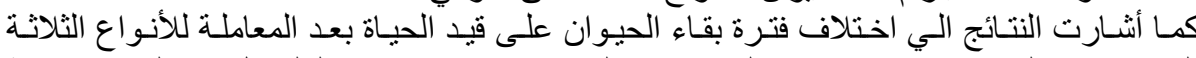

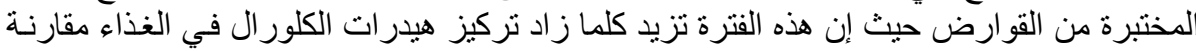

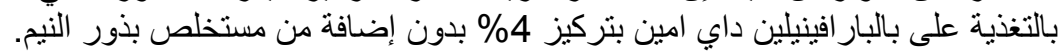

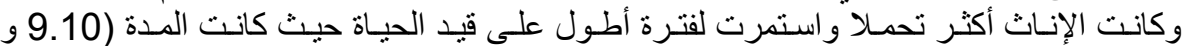

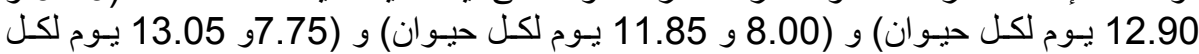
حيوان) لكل من الجرذ النيرويجي وجرذ وان الحقل النبلي و الفأر السيسي على التئ التو الي.





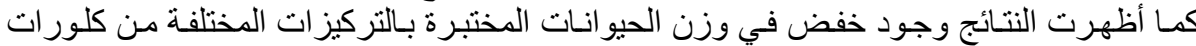

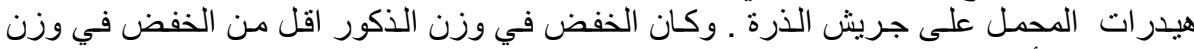

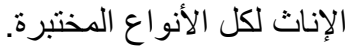

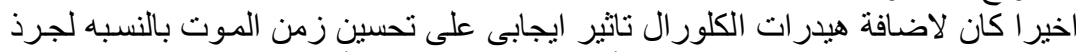

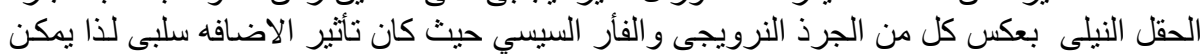

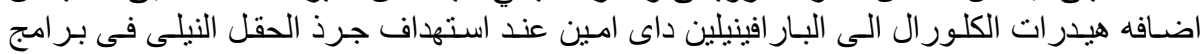

